\title{
GRAFOS Y GENÉTICA DE LOS ACONTECIMIENTOS: REPRESENTANDO LAS RELACIONES ENTRE
EVENTOS, COMUNICACIÓN NO MEDIÂTICA,
COMUNICACIÓN MEDIÁTICA Y VIRALIZACIÓN
}

GRAPHS AND GENETIC OF THE EVENTS: REPRESENTING THE RELATIONSHIPS BETWEEN EVENTS, NON-MEDIA COMMUNICATION, MEDIA COMMUNICATION AND VITALIZATION

Por:

Julián González ${ }^{1}$

Profesor Escuela de Comunicación Social

Universidad del Valle

Julian.gonzalez@correounivalle.edu.co

Resumen: Algunos acontecimientos sociales se transforman en eventos mediáticos e informativos tras complejos procesos de reelaboración y reconfiguración que los media no definen ni determinan completamente. Este artículo ofrece una propuesta de representación y tratamiento simplificado de la genética de eventos (mediáticos, no mediáticos y web). Mediante diferentes tipos de grafos es posible representar diferencias sustanciales en los procesos de generación y comunicación pública de eventos y acontecimientos sociales.

Palabra claves: Comunicación pública, génesis de eventos, comunicación social, mediaciones, periodismos y medios de comunicación.

\begin{abstract}
Some social events are transformed into media and informative events following complex processes of reworking and reshaping that, people working in the medium don't define nor fully determine. This article offers a proposal for simplified representation and treatment of the genetic of the events (media, non-media and web). Using different types of graphs, it is possible to represent substantial differences in the process of generation and publication of events and social issues.
\end{abstract}

Keywords: Public communication, genesis of events, social communication, mediation, journalism and media. 


\section{Eventos infinitos e infinitos eventos}

En 1981, Eliseo Verón (2002)² reconstruyó la manera cómo un acontecimiento (el accidente nuclear de Three Mille Island, Pensilvania, Estados Unidos) fue representando mediática y periodísticamente. La autopsia del proceso es minuciosa y detallada, y permite ver cómo van imbricándose procesos de producción de sentido y transformaciones que empiezan con el accidente nuclear el 28 de marzo de 1979, el llamado 7 horas después a la comisión reguladora de asuntos nucleares y a la guardia civil de Pensilvania y la comunicación al Gobernador; 9 horas después la Associated Press emite su primer cable gracias a que pudo enterarse del hecho por una "indiscreción de un policía". 16 horas después la AFP emitirá los primeros dos cables a partir de la información de la AP.Y 20 horas después hará su primer cable de manera directa, desde Estados Unidos. Los primeros despachos de la AP y los de la AFP serán retomados, recreados y trabajados por noticiarios locales y mundiales, introduciendo variaciones y modificaciones sustanciales hasta forjar diversas construcciones discursivas del acontecimiento, esto es, informarlo, darle diferentes formas.

Dayan y Katz (1995) tratan con la noción de acontecimiento de una manera mucho más restrictiva que Verón, circunscribiéndola a "grandes festividades de la comunicación de masas" (Dayan \& Katz, 1995, pág. 11). En su estudio, "acontecimiento televisivo" no es la gran noticia, el evento mediático de altísimo rating o uno que modifica de manera sustancial las rutinas de los espectadores, sino aquel en que convergen las tres condiciones. Es decir, constituyen auténticos rituales y ceremoniales, capaces de alterar el orden cotidiano de un número significativo de espectadores, y comportan una ruptura y alternación de la estructura de programación y el flujo de emisiones del medio de comunicación. Adicionalmente estos acontecimientos implican que el medio pueda planificar y anticipar su cobertura y registro. Ejemplo de acontecimientos y celebraciones mediáticas son los funerales de figuras y celebridades a escala global (el funeral de Michael Jackson o el Papa Juan Pablo II), el matrimonio de Diana de Gales y el príncipe Carlos, la final de un mundial de fútbol o la transmisión de la primera elección de Barak Obama, su victoria electoral y su discurso como primer presidente afroamericano en Estados Unidos el 4 de noviembre de $2008^{3}$.

Este artículo no supone ni la idea más general de acontecimiento, en tanto accidente mediatizado o acontecimiento noticioso en Verón, ni la más restrictiva -acontecimiento como celebración ritual mediatizada en Dayan y Katz. Me interesa en este artículo tratar con una noción más general (y no mediática) de acontecimiento. Por eso, para evitar malos entendidos, hablaré -inicialmente- de evento, en su sentido más lato y común: un hecho, un suceso, algo que deviene. Esto es, me interesa menos la naturaleza específica de los acontecimientos y más el hecho de que existen y se despliegan, independientemente de su eventual mediatización. Importa reconocer que la mediatización es una instancia y momento constitutivo de algunos acontecimientos, pero -obviamente- no es una condición sine qua non de su existencia. Es indispensable volver a pensar los acontecimientos independientemente de su potencial génesis mediática y destacar -aunque parezca obvio- que hay más comunicación social de acontecimientos y eventos que comunicación mediática de los mismos, y que la comunicación pública no se restringe a lo que pasa por los media en tanto instituciones e industrias. 
En la edición del jueves 10 de octubre de 2013 del noticiero CM\& hubo una noticia de medio minuto de duración que informaba sobre la protesta de un grupo de Madres Comunitarias en la Plaza de Bolívar de Bogotá, frente a la Casa de Nariño. Las mujeres exigían vinculación formal con el Instituto Colombiano de Bienestar Familia (ICBF), pensión por su trabajo de décadas - algunas llevaban más de 20 años de servicio- y regularización contractual. Exigían que el presidente Juan Manuel Santos las recibiera y, en tanto eso no ocurriera, tomaron la decisión de ir desprendiéndose de sus ropas, cada día, hasta conseguir su propósito de hablar con él. Ese jueves hicieron el primer gesto ante las cámaras: se quitaron la blusa y aseguraron que el viernes 11 de octubre se quitarían el sostén. Se trata de mujeres adultas, de entre 30 y 60 años, de sectores populares. La misma noticia apareció publicada en la edición impresa de El Tiempo, el día 11 de octubre de $2013^{4}$. La nota de prensa considera detalles e información que la noticia de televisión no incluía: nombres de algunas de las voceras (p.e., Olinda García, presidenta nacional del Sindicato de las Madres Comunitarias), declaraciones de la directora encargada del ICBF (Adriana González Maxcyclak), cifras ${ }^{5}$, detalles sobre el modo en que se paga el trabajo de las madres comunitarias (bonificación mensual equivalente a un salario mínimo, pero no opera como un contrato de trabajo), información proporcionada por González acerca de las dificultades y limitaciones que existen para que se puedan pensionar, dado que no han cotizado, datos sobre un programa del Sena para cualificación de madres comunitarias en enseñanza en la primera infancia, y algunas referencias sobre la estrategia gubernamental denominada de Cero a Siempre, orientada a la atención de niños entre 0 y 5 años. Adicionalmente, hay una fotografía en que aparecen cuatro mujeres despojándose de sus camisas y un grupo de madres comunitarias portando pancartas y encadenadas, sobre las escalinatas del Palacio de Nariño (Figura 3).

La protesta de las Madres Comunitarias es un evento. Podemos convenir en llamar Evento (E) a todo acontecimiento. Esta declaración sencilla, por supuesto, no dice mucho porque, a la vez, uno tendría que definir qué es acontecimiento y, a lo sumo, termina creando alguna forma más o menos sofisticada y circular de definición ('todo acontecimiento es la emergencia de un fenómeno a partir de un conjunto de eventos previos o antecedentes'), o deriva en una definición formal abstracta y limitada que no dice mucho ('evento es todo cambio en el estado de un sistema'), lo que siempre conduce a una suerte de sin salida: ¿puede haber un no-evento? Las tentativas de dirimir en el plano lógico y nominal la incesante creatividad de la historia y devenir real generalmente terminan fracasando. Por lo pronto convengamos en que hay Eventos y que éstos son infinitos. El desplazamiento un milímetro de una gota de agua está lleno de infinitos eventos tanto en su devenir en el tiempo inmediato como en términos de su pasado y de su porvenir. El movimiento de una gota de agua en un nanómetro (milmillonésima parte de un metro o $10^{-9}$ metros) considera muchos infinitos en sí mismo: el movimiento de cada átomo en la gota de agua, la interacción entre la tensa superficie de la gota de agua y las moléculas de aire o de las superficies sobre las que rueda, los efectos de tales interacciones por fuera de la gota de agua ${ }^{6}$, todos los procesos previos que permitieron la génesis de la gota de agua, la gravedad que la hace caer, la superficie sobre la que se desliza... En fin. Castoriadis (1991) 
ha sabido mostrar cómo, justamente, uno de los rasgos de la racionalidad moderna es que ha hecho tratable lo infinito a través de procedimientos finitos, imponiéndole a lo ilimitado límites parciales que le permiten operar técnica y lógicamente con aquello que, de otra manera, sería intratable. Ha vencido lo que no tiene límites (apeiron) poniendo límites provisionales y transitorios que le permiten obrar con eficiencia local aunque ello implique sacrificar y renunciar a la comprensión de totalidades y a la previsión de consecuencias globales. De esta manera, creamos designaciones que a) aplazan o desplazan o posponen lo no tratable y b) alientan la construcción de procedimientos para tratar con lo tratable.

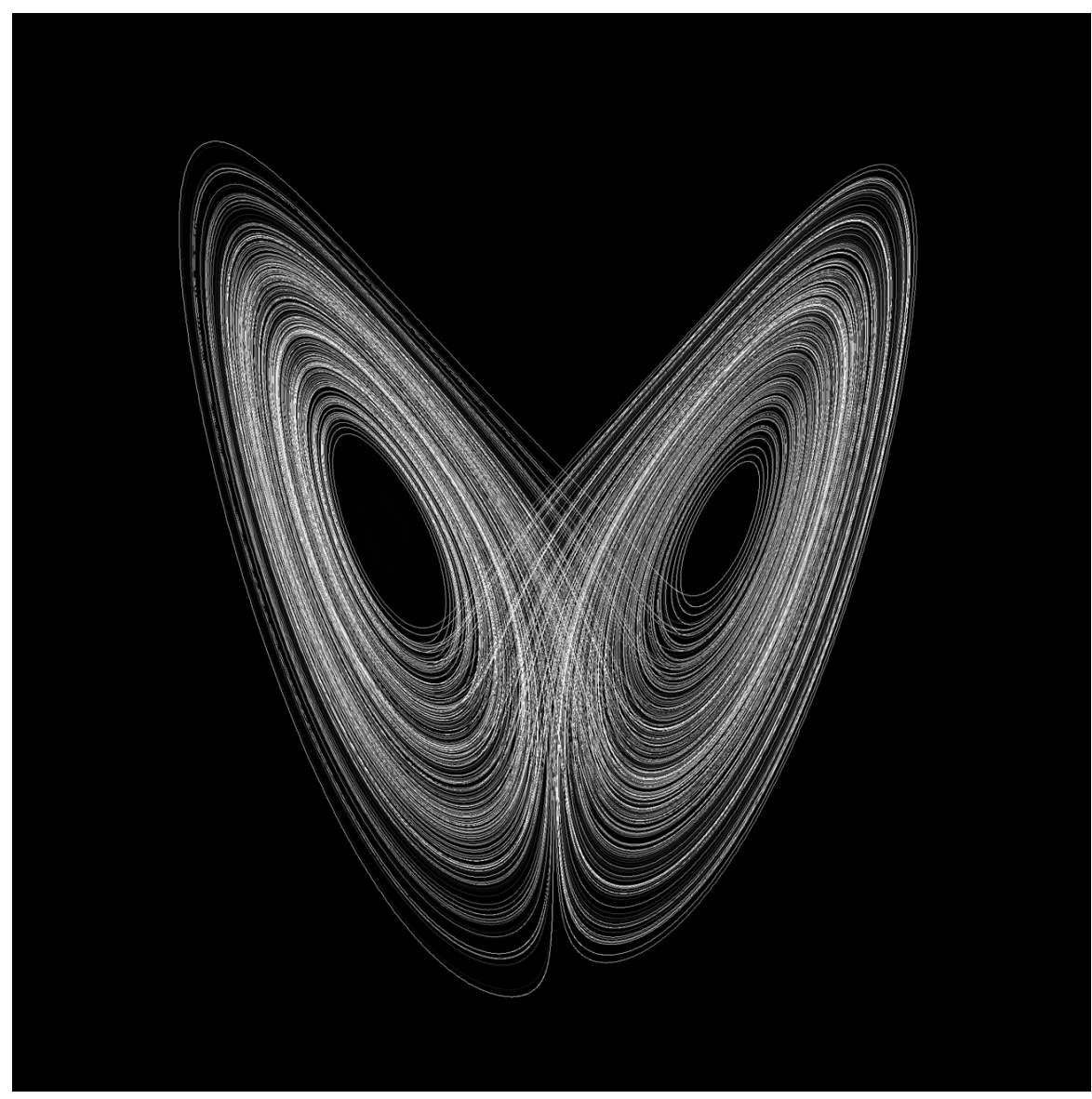

Figura 1. Atractor de Lorenz o trayectorias del sistema de Lorenz, y la importante noción de sensibilidad de los sistemas dinámicos a pequeñas modificaciones en las condiciones iniciales. Este gráfico describe los cambios de trayectoria (puntajes, resultados) de un sistema no lineal cuando se modifica infinitesimalmente sus condiciones de inicio o a partir de ciertos valores en los parámetros. La forma de mariposa de la imagen, sin duda, ha contribuido a alentar el mito popular del Efecto Mariposa, aunque -en sentido estricto- ilustra la idea de caos, esto es, un fenómeno que, aunque no es predecible, no es aleatorio. Esto es, un fenómeno respecto al cual no podemos decir qué pasará una fracción de tiempo después, pero del cual podemos afirmar que no ocurre cualquier cosa. 
De la misma manera, volviendo a nuestro tema, podemos hacer una denominación para designar lo tratable y aplazar (para un después indefinido) lo que no podemos tratar [(por ejemplo, el hecho de que los eventos, acontecimientos o actos están constituidos a su vez de eventos, acontecimientos o actos, que a su vez están hechos de eventos, acontecimientos, que a su vez... ad infinitum (ver Figura 2)]. Podemos convenir una designación finita (Evento) para ese infinito (Evento hecho de eventos hechos de eventos...).
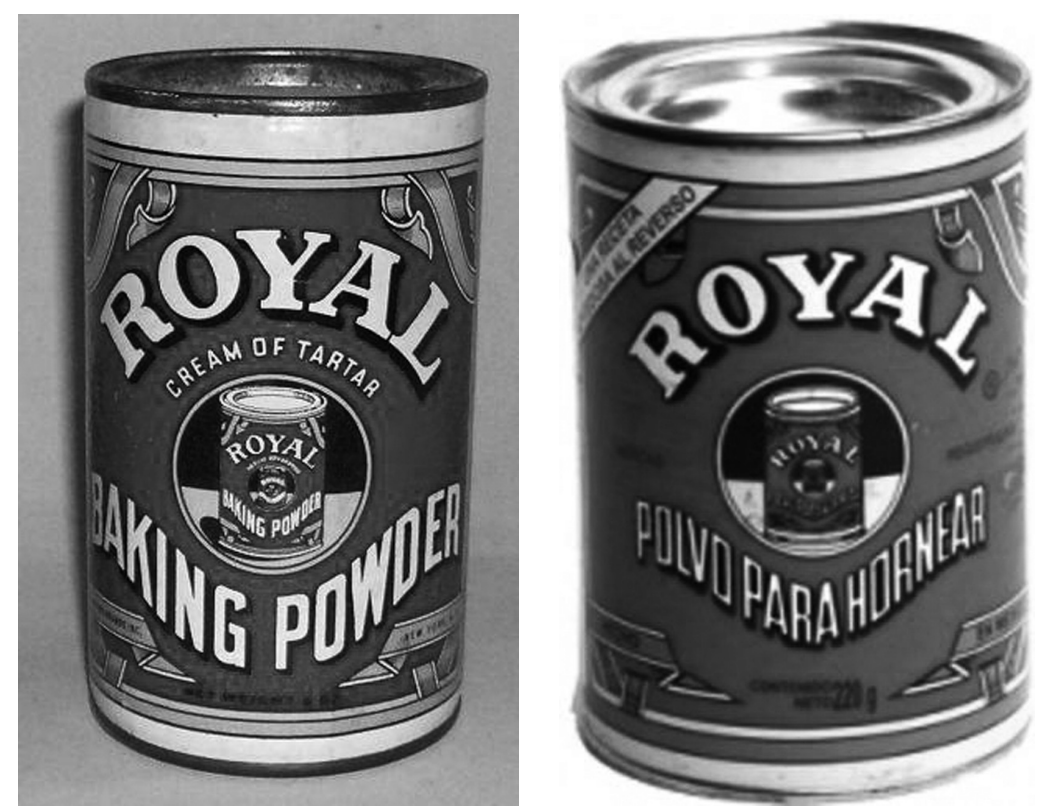

Figura 2. Fantaseé muchas veces con esta imagen hipnótica del infinito que contiene infinitos infinitos. A veces creo que este fue el primer videojuego que jugué en mi vida, mucho antes que el caleidoscopio (mi segundo videojuego). Contabilizaba cuántos tarritos de polvo Royal alcanzaba a ver, cuántas capas podía penetrar, y me quedaba minutos enteros fantaseando con el asunto.

Las madres comunitarias que protestan frente al Palacio de Nariño son un Evento hecho, por supuesto, de infinitos eventos. Una narración periodística bien pudo ocuparse de un evento conexo, la desnudez de estas mujeres, y subrayar, por ejemplo, el hecho de que en los medios de comunicación es poco frecuente encontrar imágenes de cuerpos y mujeres desnudas como éstas aunque esta diversidad corporal sea la norma y no la excepción (ver Figura 3). Por contraste, los cuerpos mediáticos -los que ofrecen los mercados de la moda, de la publicidad, los deportes, los melodramas y la farándulaserían la excepción, no la regla. Entonces la nota repararía en las formas de racismo y exclusión corporal que los medios de comunicación promueven al privilegiar ciertos patrones de la apariencia corporal. Pero volviendo atrás, nótese que la fotografía del periódico ElTiempo (del fotógrafo Mauricio Moreno) y las imágenes del noticiero CM\& subrayaron el acto de despojarse de la camisa y quedar en sostén (Figura 3) por sobre otros sub-eventos constitutivos del evento. 


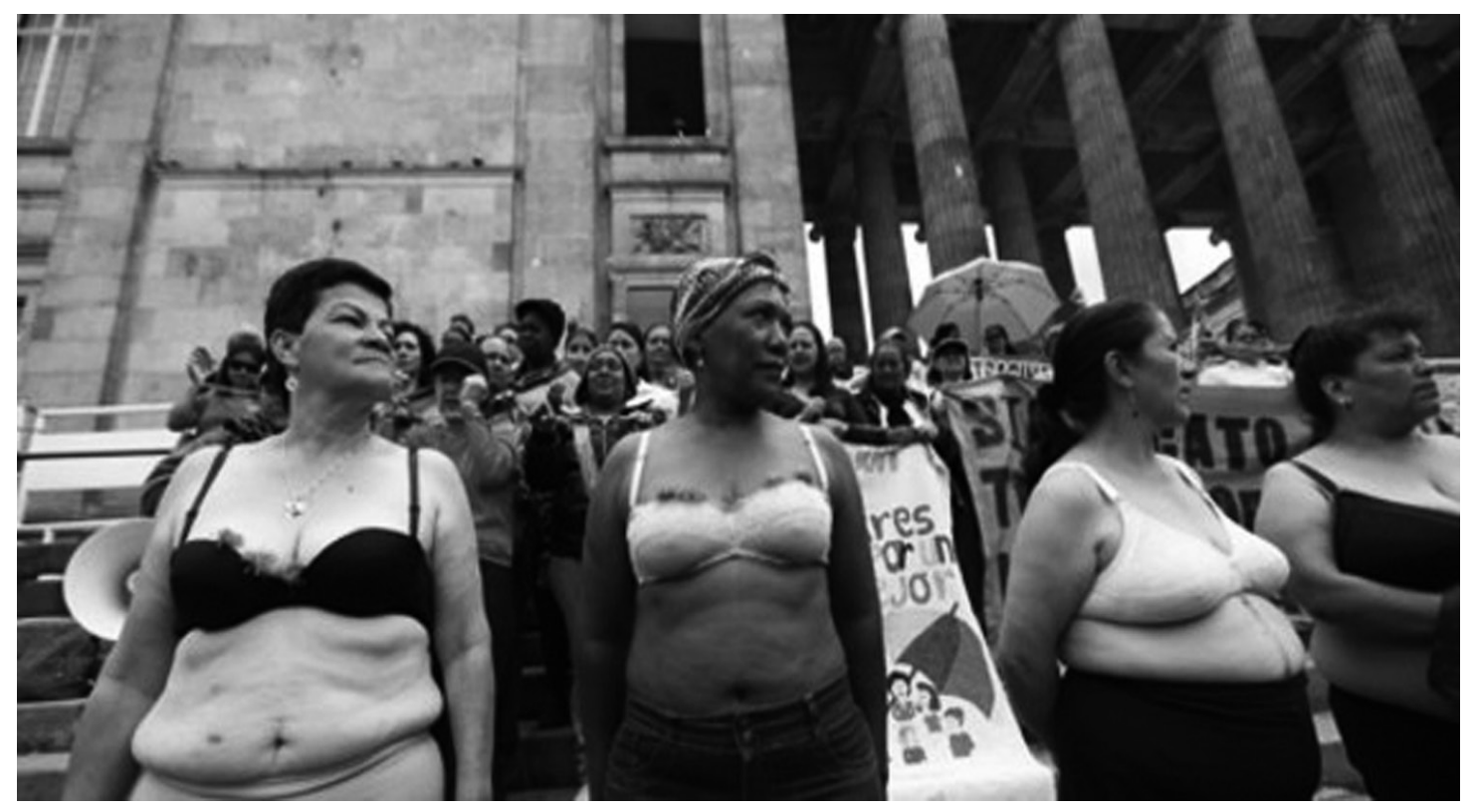

Figura 3. Foto Mauricio Moreno/El Tiempo. La fotografía de la versión impresa del diario registró los eventos algunos segundos previos a este momento: en esa fotografía, tres de las cuatro mujeres están quitándose las blusas. 11 de octubre de 2013.

Entonces, tenemos que un Evento es siempre una red de eventos y esa red es un sistema de infinitos elementos (eventos conectados entre sí). A su vez cada Evento puede atraer otros eventos de los que se hará constitutivo. Por ejemplo, uno puede imaginarse a Santos dividiéndose entre ir a ver el partido de la Selección Colombia contra Chile, el 11 de octubre de 2013, en Barranquilla, y calculando si vale la pena exponerse a la rechifla del público, considerando que ya ha pasado por eventos similares en Cali (recuérdese su desaire durante la inauguración de los World Games, en julio de 2013). El enorme descontento con su gestión, si le damos crédito a las encuestas publicadas recientemente por los medios, hace que él y sus asesores lo piensen dos veces antes de cada aparición pública. De esta manera, el Evento A (silbatinas de Cali), Evento B (encuestas), están enlazados con el Evento C (¿voy o no voy a Barranquilla?). Es decir, hay eventos que se conectan con otros. No sabemos si, por ejemplo, la amenaza de las Madres Comunitarias (Evento A) provocará que el presidente se reúna con ellas (Evento B). Pero lo cierto es que al menos dos medios (El Tiempo, CM\&) cubrieron el Evento A.

Es decir, no sólo hay el evento (Figura 4), sino que ese evento, a su vez, está hecho de eventos (Figura 5), y hay eventos que arrastran casi gravitacionalmente a otros eventos (Figura 6). 

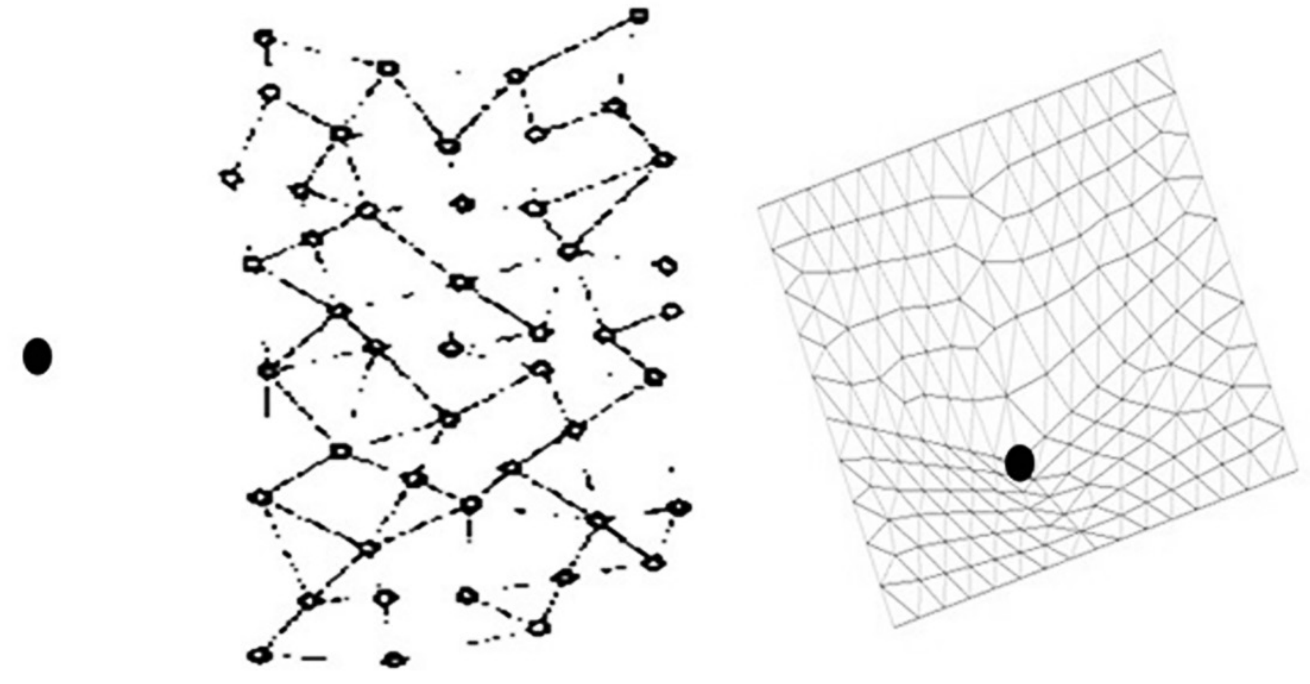

Figura 4

Figura 5

Figura 6

Hay evento (figura 4, punto), hecho de eventos (figura 5), que arrastra eventos (figura 6).

\section{Eventos y grafos de relaciones}

Pero es interesante notar que pueden distinguirse dos tipos de eventos: el evento de referencia (las Madres Comunitarias y su acto de protesta) y el evento mediático o mediatizado periodístico (la nota de prensa y televisión sobre las Madres Comunitarias que protestan). Entonces a partir de esta sencilla distinción se advierten dos fenómenos muy interesantes: no es posible una cobertura completa (exhaustiva) de ningún evento porque son infinitos internamente (están hechos de infinitos eventos constitutivos, derivan de infinitos eventos antecedentes y procuran infinitos eventos consecuentes) y, segundo fenómeno, hay $n$ eventos de referencia que jamás se convierten en eventos mediáticos. Los eventos mediáticamente comunicados jamás son exhaustivos y completos, y por los media informativos no circulan todos los eventos sociales. Estos dos fenómenos son obvios y, sin embargo, conviene recordarlos porque tienen consecuencias concretas para el ejercicio periodístico.

¿Cómo ocurre que ciertos eventos se mediatizan y otros no? ¿Y cómo sucede que habiendo eventos infinitos en número y, a la vez, infinitos en su propia constitución, el periodismo opera con relativa eficiencia y se lo sigue considerando fundamental entre los procedimientos y prácticas de representación y comunicación social de lo real informado? 
Nótese que queda un saldo preciso derivado de la anterior reflexión. Pensemos en un topos concreto y más o menos circunscrito: pensemos en un país como Colombia o una ciudad como Cali. En ese lugar ocurren infinitos eventos ${ }^{7}$ (E) todo el tiempo, de los cuales sólo algunos son mediatizados e informados $(\mathrm{eM})^{8}$; pero nótese adicionalmente que eM es a la vez un evento (E) susceptible de ser mediatizado, como ocurre cuando un medio cita lo que dijo, presentó o publicó otro medio. De ambos, E y de eM, personas y grupos sociales de muy variadas características hablarán o comunicarán socialmente algún aspecto. Es decir, hay un tercer tipo de eventos que son las diversas formas de comunicación no mediáticas que las personas ponen en marcha a partir de eventos (E) y eventos mediatizados (eM). Esos actos de comunicación social no mediáticos son, a su vez, eventos en sí mismos (eCs). De esta manera hay E, hay eM y hay eCs alrededor de E y eM que, a su vez, puede ser mediatizado (EM) o comunicado por otro medio (Figura 7).

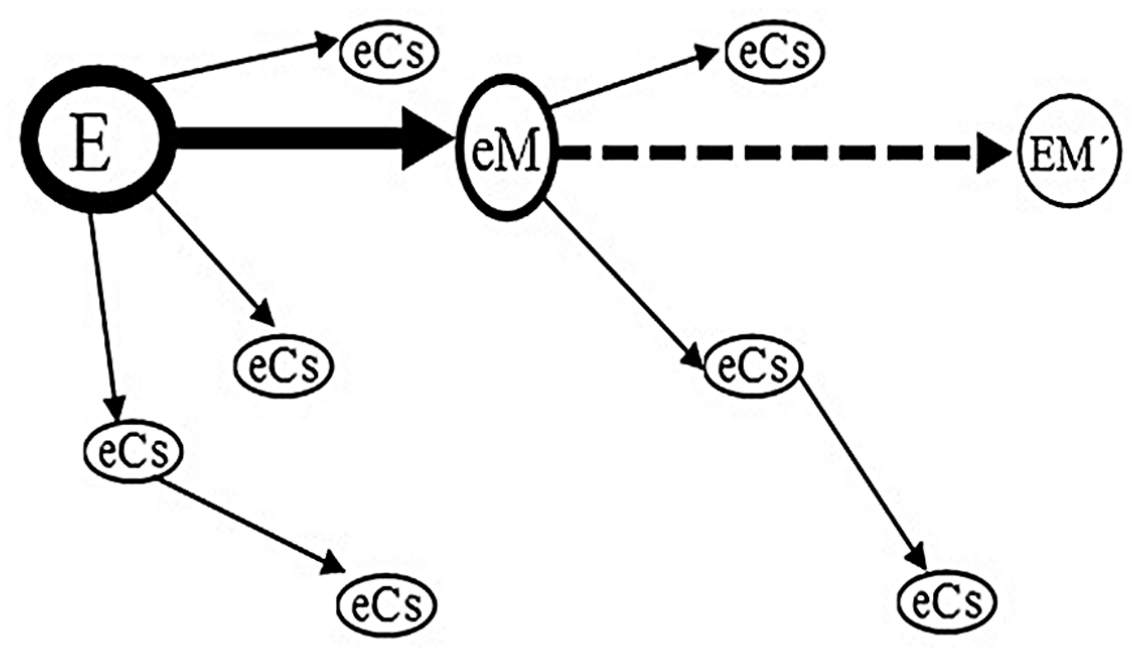

Figura 7. Tenemos un evento (E), que deriva en un cinturón de eventos comunicados socialmente no mediáticos (eCs), esto es rumores, comentarios, narraciones de testigos, etc, antes de convertirse en un evento mediatizado (eM), que a su vez procura nuevos eventos comunicados socialmente (eCs), y puede ser citado, reproducido o analizado por otro medio de comunicación, esto es, se transforma en un evento mediático (EM') derivado de uno mediatizado (eM).

Compliquemos las cosas un poco más: nótese que, además, hay muchos E que no son mediatizados y sin embargo son socialmente comunicados a través de, por ejemplo, el chismorreo, el relato y el rumor, la conversación cotidiana primaria y básica entre las personas. Esto es, se desarrollan como eventos comunicados socialmente (eCs), que a su vez se convierten en eventos susceptibles de mediatización ("según rumores ampliamente difundidos, José Daniel Gómez, alias el Zarco, permanecería oculto en la Vereda La Pinta, jurisdicción de El Carmelo...”) o constituyen nuevas formas de circulación y divulgación no mediáticas. O podrían sencillamente hundirse en el silencio general (Figura 8) ${ }^{9}$. También hay varios eventos que son, en primer lugar, 
mediáticos, cada vez más modulados, definidos y moldeados por los requisitos y condiciones que imponen las industrias de medios de comunicación: un noticiero de televisión, en sí mismo, es un evento mediático (EM). Algunos se quejan de cómo, progresivamente, los partidos de fútbol se van ajustando a las condiciones que imponen las empresas de medios que compraron los derechos de transmisión a la Federación Colombiana de Fútbol. En este caso no se trata de eventos completamente mediáticos, pero sí crecientemente dominados por algunas de las condiciones de producción televisiva. Los reality shows como Protagonistas de Nuestra Tele son eventos fuertemente mediáticos. El control sobre su desarrollo y puesta en escena pertenece casi completamente a la empresa de medios que los produce. Pero, adicionalmente, hay eventos que sin ser mediáticos son concebidos y pensados teniendo como condición su segura exposición a los medios, como la protesta de las Madres Comunitarias y su streap tease calculado, entre otras, para los noticieros de televisión y para las cámaras. Igual los eventos mediatizados (eM) y los mediáticos (EM) son eventos susceptibles de ser socialmente comunicados hasta popularizarse ampliamente, o pueden hundirse con el correr de los días en silencios y olvidos profundos y duraderos.

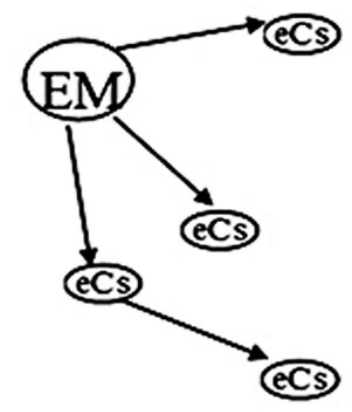

A

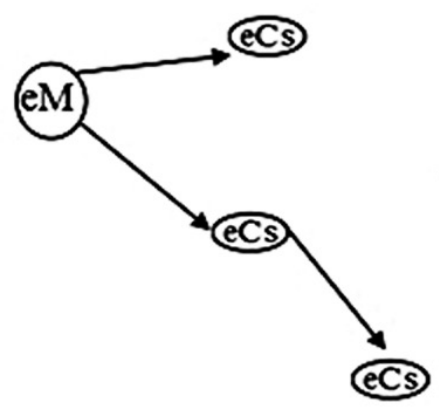

B

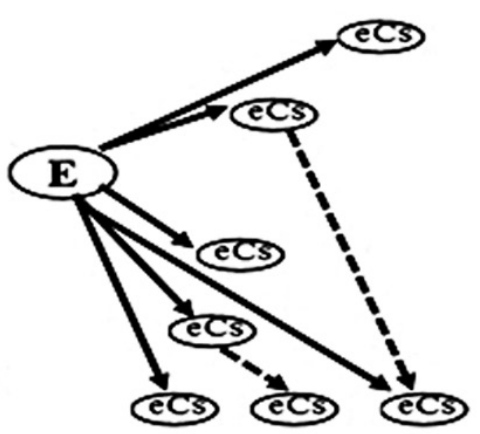

$\mathbf{C}$

Figura 8. Tenemos (A) un evento mediático (EM) o cuasimediático -un Reality, un concurso de televisión, un comercial publicitario, un error del presentador de noticias, un partido de fútbol transmitido por televisión- que deriva en un cinturón de eventos comunicados socialmente no mediáticos (eCs). También hay (B) un evento mediatizado (eM) que puede generar, alrededor, un cinturón de eventos eCs. Finalmente puede haber (C) eventos (E) -no mediatizados ni mediáticos- que generan cinturones de eCs, como cuando las personas hablan de los acontecimientos de su barrio o conversan de lo que otros han conversado acerca de esos acontecimientos ( $\mathrm{E} \rightarrow \mathrm{eCs} \rightarrow \mathrm{eCs}$ ).

La existencia de canales gratuitos de circulación de videos e imágenes en la web comoYou Tube han extendido las condiciones y posibilidades de mediatización de todo tipo de eventos, de manera tal que un Evento (E) puede procurar una versión digital que migra hacia laWeb (Edg/web: Evento digital/web). Ocurre en algunos casos que este evento web se viraliza, tal como ocurrió con el Documental 970, o con el primer video de Gangnam Style (Figura 9). Además, su viralización se convierte, en sí misma, en evento susceptible de cierta mediatización como ocurre cuando algunas secciones de noticieros hacen mención de un video reproducido cientos de millones de veces en You Tube ${ }^{10}$ (Figura 10). 


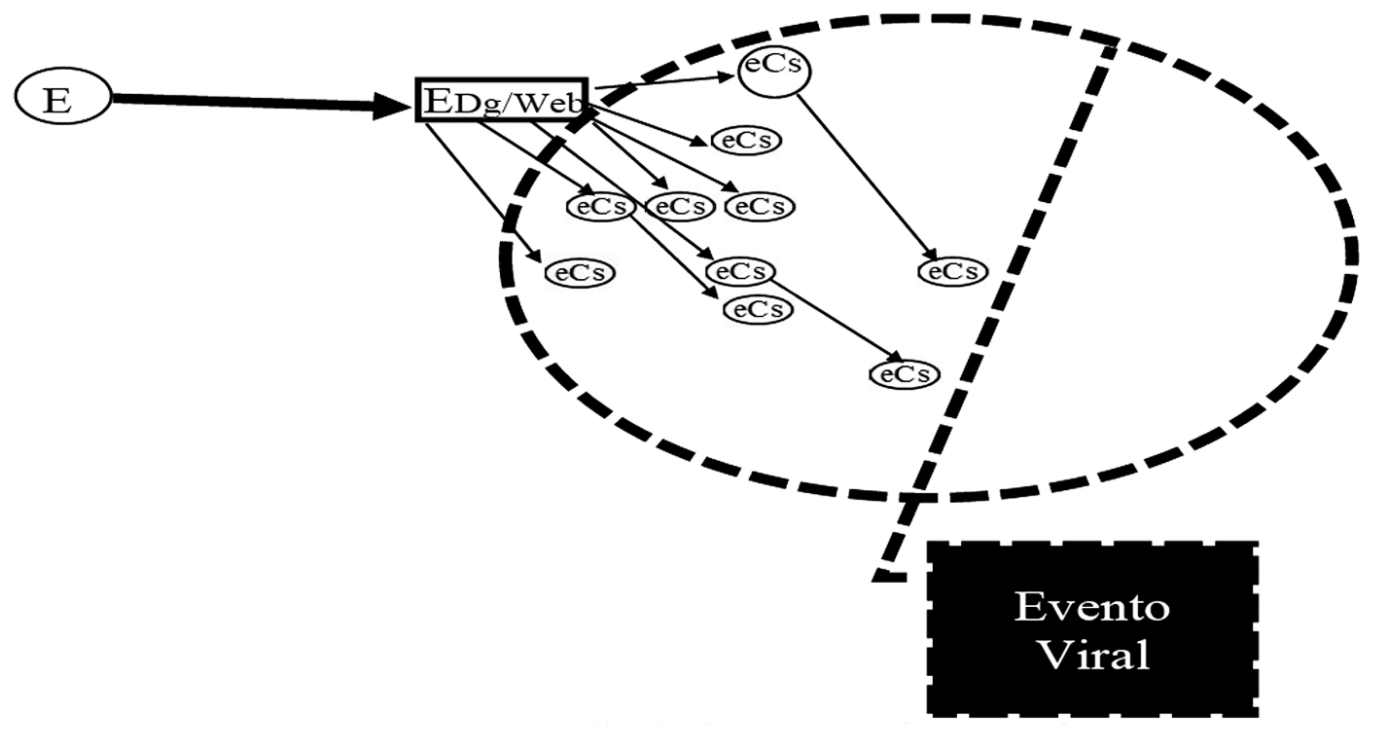

Figura 9. Un Evento (E) es filmado y digitalizado, luego se lo dispone en la Web (You Tube, Facebook, distribución vía correos electrónicos). Usuarios de diverso tipo comienzan a verlo y lo comentan, lo redistribuyen o lo reproducen, todos eventos comunicacionales no mediáticos. Con el correr de los días se convierte en evento viral $(\mathrm{eV})$.

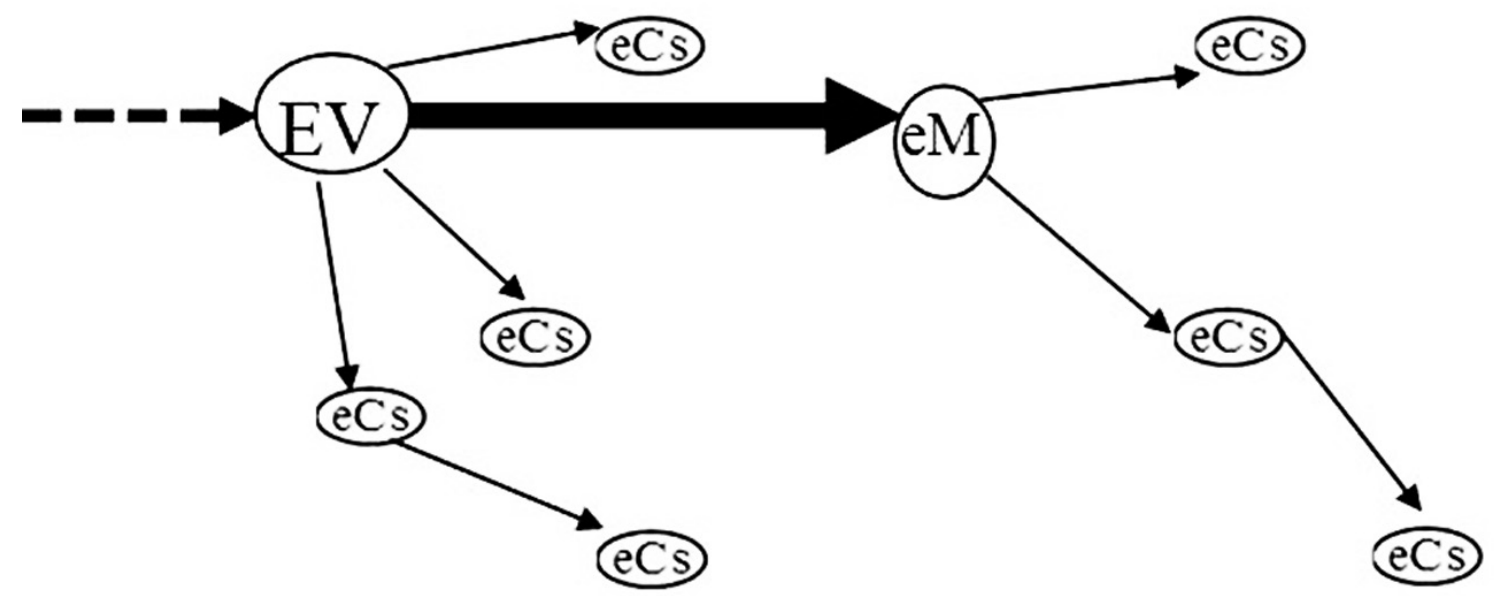

Figura 10. Un evento viral (EV), esté o no fundado en un evento (E) previo, puede considerar un cerco de eventos comunicacionales no mediáticos (eCs), y derivar en evento mediatizado (eM), por ejemplo, una sección del noticiero en que se comenta la condición viral del video. 
Cerremos añadiendo algunas anotaciones. Hay eventos mediatizados y eventos mediáticos que migran a la web, y se hacen virales (Figura 11). Hay eventos que duraderamente no se mediatizaron nunca, tuvieron muy baja comunicación social, permanecieron largo tiempo silenciados, y de repente -en virtud de una revelación, una investigación periodística, una investigación judicial, una denuncia o un hallazgo casual- se hacen mediáticos, se comunican de manera intensiva y, en algunos casos, se viralizan (Figura 12). Otros permanecerán ocultos y en silencio por los siglos de los siglos, apenas conocidos a través de rumores, relatos fragmentarios, indicios frágiles, secretos (Figura 13).

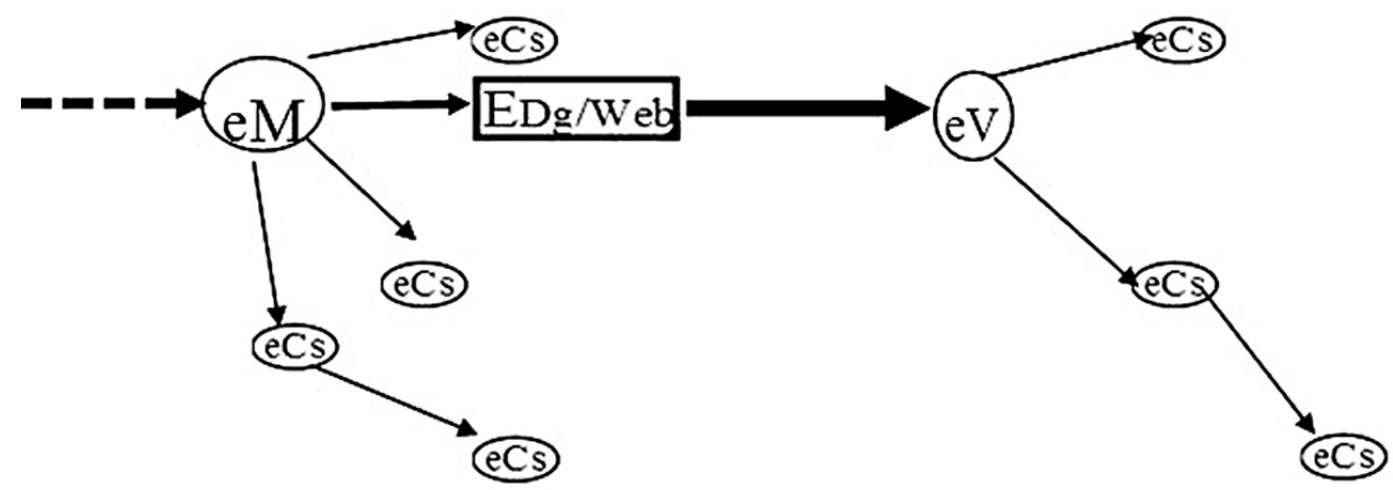

Figura 11. Un evento mediatizado $(\mathrm{eM})$, potencialmente rodeado de un cinturón de eventos comunicacionales no mediáticos $(\mathrm{eCs})$, se puede convertir en viral $(\mathrm{eV})$

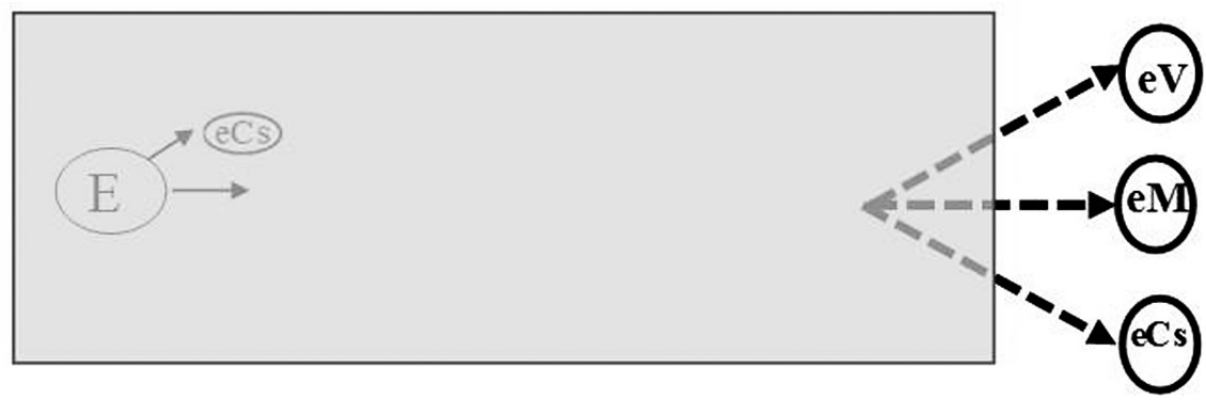

Figura 12. Un evento del pasado es posteriormente des-cubierto, revelado y publicado mediante un proceso de mediatización, comunicación social no mediática o viralización, o mezcla de los tres tipos de eventos comunicacionales. 


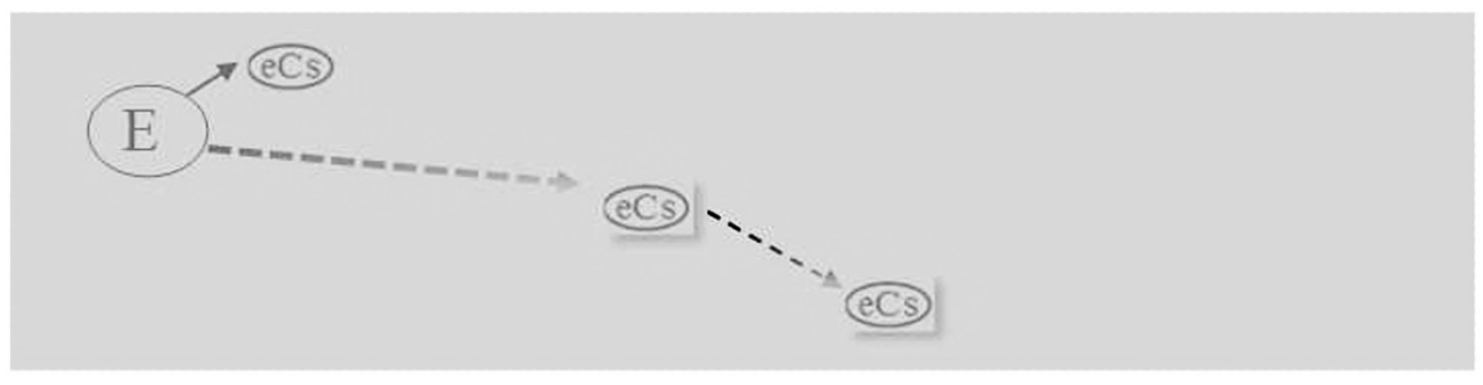

Figura 13. Un evento que no consigue hacerse visible socialmente, de manera significativa, y permanece oculto, olvidado, apenas ligado a débiles eslabones de rumores y secretos, indicios fragmentarios y frágiles.

Y, en el otro extremo, hay eventos mediatizados que gozaron en un momento de importante visibilidad y relevancia (alta presencia y replicación mediática y relativa comunicación social no mediática) y terminaron, más o menos rápidamente, hundiéndose en el silencio y el olvido (Figura 14). Y hay eventos no mediatizados altamente comunicados y, por ejemplo, intensamente viralizados, que jamás consiguen mediatizarse (jy ni falta que les hace!). Ver Figura 15.

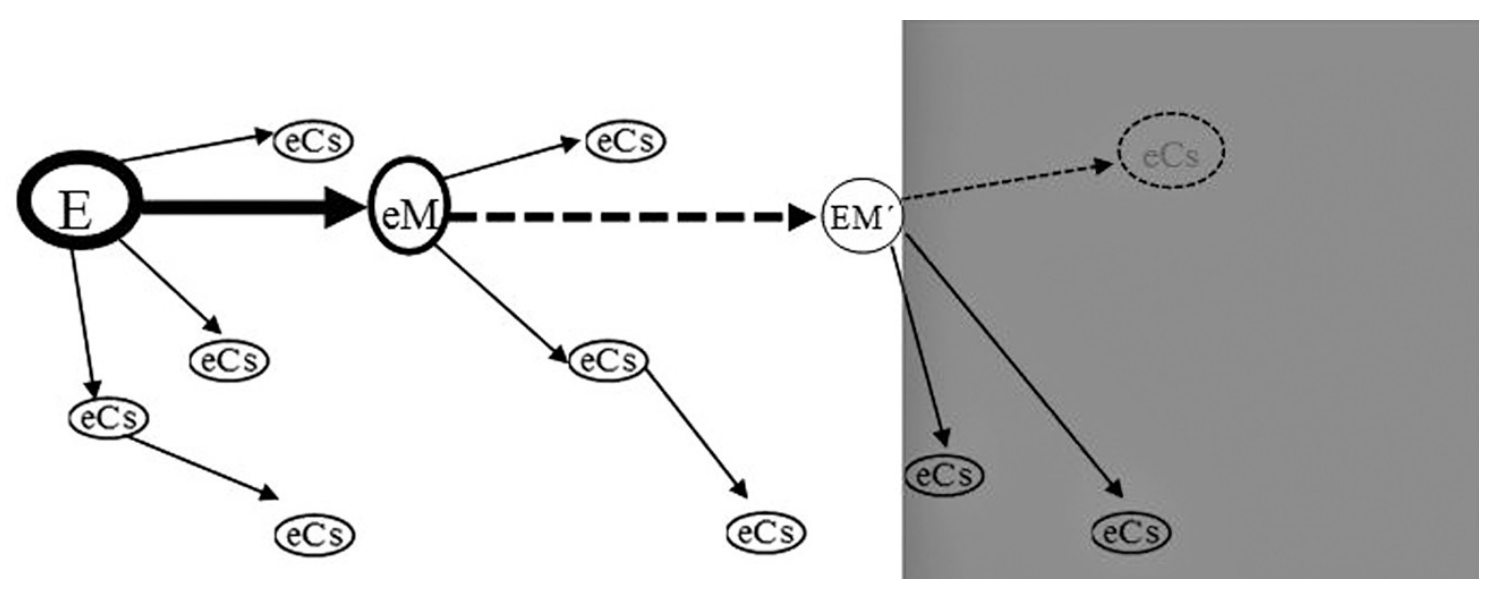

Figura 14. Un evento que en algún momento consideró amplias formas de comunicación social, mediatización y hasta su transformación en evento mediático (ejemplo, la vida y actividades de Pablo Escobar, 1949-1993, informada regularmente en noticieros de televisión (eM) de la década de los 1980 y comienzos de los 1990, se convierte luego en evento mediático, EM, como sucedió con la serie televisiva, Escobar: El Patrón del Mal. Puede ocurrir que en un par de décadas deje de ser parte de nuestras referencias, tal como pasó con Sangre Negra cuya historia y acciones fueron intensivamente referidas en medios impresos y radio desde comienzos de la década de 1950 hasta su muerte en abril de $1964{ }^{11}$. 


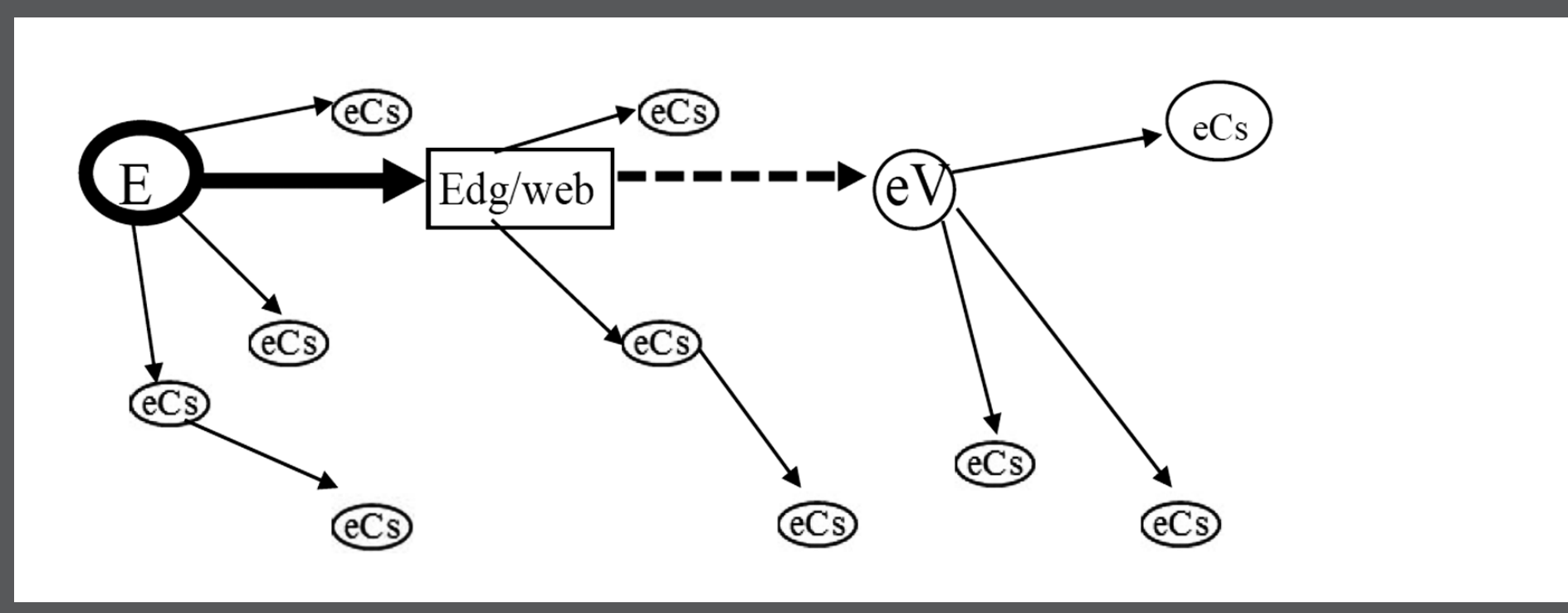

Figura 15. Un evento considera una amplia circulación y comunicación social no mediática (eCs), deriva en evento viral en la web (eV), sin que nunca sea mediatizado (eM) o se convierte en evento mediático (EM).

¿Por qué importan estas distinciones adicionales? Porque ponen de relieve la condición dinámica (esto es, asociada al tiempo) de los fenómenos de mediatización, de comunicación social no mediática y de viralización, y porque enfatizan que mediatización no equivale a comunicación social intensiva y fuerte, que viralización y comunicación social intensiva y fuerte no siempre se traducen en mediatización, y que ninguna mediatización tiene asegurada una prolongada presencia social. Pero además permite postular una idea sencilla pero decisiva a la hora de pensar el periodismo y, en general, la comunicación social mediatizada: sin el trabajo de comunicación social no mediática (eCs) hecho de manera capilar, cara a cara, en redes sociales de primer orden, en las conversaciones y comunicaciones más o menos reducidas de la vida académica, en los rumores y charlas soto voce, en las charlas de almuerzo, en los relatos memoriosos de los viejos y jóvenes, en el incesante parloteo de los niños y jóvenes durante los recreos escolares, en los comentarios y I like en la web, en la divulgación a través de correos electrónicos y diálogos vía teléfono móvil y fijo, esto es, sin este amplio cinturón de formas de comunicación social no mediática y su espesura, la eficacia de los eventos mediáticos y mediatizados sería sencillamente limitada.

Adicionalmente, estamos en condiciones de hacer seguimientos más o menos sistemáticos de la génesis comunicacional de eventos, la forma en que se mediatizan, se viralizan, colapsan, se amplifican y mueren duraderamente. Es posible trazar grafos específicos del modo como un evento (E) se transforma en viral (eV), por ejemplo: hacer seguimientos, examinar trayectorias y estudiar patrones, establecer comparaciones, mediante este tipo de representaciones simples. Cada uno de los grafos que he presentado en las Figuras 7-15 son trayectorias posibles de eventos sociales y eventos comunicacionales. Adicionalmente, este tipo de esquemas puede ayudarnos a tratar y examinar de qué manera un evento (E) se hace comunicacionalmente muy denso hasta arrastrar otro tipo de eventos, cómo el 5 a 0 de Colombia contra Argentina (5 de septiembre de 1993) o el asesinato de Jorge Eliecer Gaitán (9 de abril de 1948) ${ }^{12}$. 
Por lo pronto podemos decir del evento (E), protesta de las Madres Comunitarias del 10 de octubre de 2013, que derivó en, al menos, dos mediatizaciones. Luego el 12 de octubre de 2013, en el canal del Congreso, a las 9:00 pm, se retransmitió una entrevista que el senador del Polo Alexander López le había hecho una semanas antes a dos líderes del movimiento de madres comunitarias del ICBF en el programa Nuestros Derechos. Es decir, un EM (entrevista en el Canal del Congreso) se relanzó debido a la protesta pública mediatizada los días 10 y 11 de octubre de 2013. Y hay un cinturón de eventos comunicacionales no mediáticos que van desplegándose alrededor de la protesta: por ejemplo, esta curaduría; las conversaciones de las personas que conocen a las líderes; los periodistas en los medios que decidieron cubrir la protesta; la directora encargada del ICBF y varios funcionarios que se vieron conminados a responder a los medios tras, quizás, una llamada del Palacio de Nariño para que encarara el tema. No sabemos si habrá algún nivel de viralización de la protesta. Pero es posible comenzar a hacer un seguimiento de la génesis comunicacional del evento usando algunas de las distinciones sugeridas, tal como se ofrece en el grafo siguiente (Figura 16).

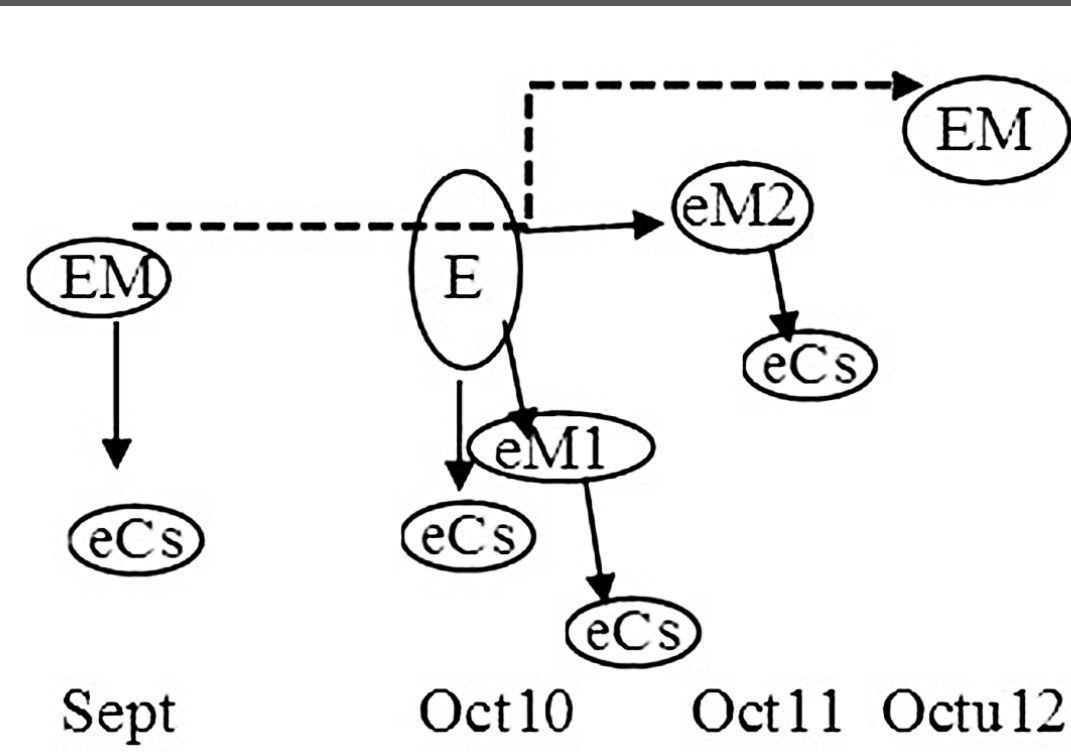

Figura 16. Ya a finales de agosto se presentaron las primeras protestas de las Madres Comunitarias por la falta de claridad sobre su condición laboral. Algunas de estas protestas fueron mediatizadas (eM). En septiembre el senador Alexánder López, en Nuestros Derechos, programa del Canal del Congreso, entrevistó a dos líderes de las madres comunitarias (EM), lo que debió desplegar varios eCs (por ejemplo, sospechas entre miembros del congreso y el gobierno de que, tras la organización de las madres comunitarias, está el Polo; o acusaciones de oportunismo político del Polo; o aprobación e muchas personas por la decisión de invitar a la líderes del movimiento a ser escuchadas en este programa debido al silencio mediático respecto a las legítimas reclamaciones de las madres comunitarias. El 10 de octubre de 2013 hacen el plantón frente a la Casa de Nariño (E) que es mediatizado por El Tiempo (versión impresa y on line) el 11 de octubre, y por el noticiero CMI el mismo 10 de octubre. Para la versión digital como impresa, El Tiempo entrevistó a la directora encargada del ICBF, y seguramente hubo un conjunto de conversaciones gubernamentales sobre el tema durante y después del evento (E) y de su publicitación mediática (eM). El Canal del Congreso retransmitió el 12 de octubre la entrevista que Alexánder López había realizado con dos de las líderes del movimiento madres comunitarias a finales de septiembre. 
De esta manera podemos hacer representaciones de diversos tipos de itinerarios, transformaciones y trayectorias de eventos, reconstruyendo - hasta donde sea posible- la urdimbre que los va modulando y comunicando. El seguimiento y reconstrucción de la génesis o genética comunicacional de eventos pueden ayudar a moderar los excesos del mediacentrismo, que suele explicar a partir de la acción de los medios de comunicación la génesis discursiva de ciertos acontecimientos y su impacto social. Adicionalmente, trazar y tratar con grafos la génesis de acontecimientos es mucho más viable hoy gracias a que, en la web, suelen quedar rastros datados/datables de los cuatro tipos de eventos derivados de E (eCs, EM, eM y web-virales).

\section{Eventos periodísticos}

Un evento (E) obviamente no es idéntico a su versión periodística mediatizada. La mediatización periodística esquematiza el evento siguiendo algunas pautas y procedimientos relativamente estandarizados y codificados. El tratamiento periodístico de los eventos implica diversas combinatorias de relatos y relaciones de acciones, descripciones (de objetos, cosas, lugares, personas), declaraciones (de personas), referencias a documentos de múltiples características e inferencias o hipótesis. Géneros, formatos, tips, procedimientos de rastreo de datos, modelos autorales, modos de entrevistar y pautas de trabajo, una amplia y extendida manualística, hacen parte del repertorio y utillaje compartido de esa comunidad de trabajadores intelectuales llamados periodistas. ¿En qué sentido puede afirmarse que este repertorio de procedimientos es clave para entender los procesos de mediatización periodística?

Martín Serrano (1985/1997) ha elaborado desde la década de 1970 una compleja teoría para tratar con lo que llama las mediaciones sociales. Hay varias ideas básicas en esta teoría. Una de las esenciales es la siguiente: los seres humanos hemos ampliado nuestra capacidad para ejercer dominio y orientar el funcionamiento de la sociedad y, por supuesto, ejercemos control creciente sobre "la naturaleza". Esto es, tenemos creciente capacidad para ajustar el devenir de la sociedad a "designios", propósitos, proyectos, concepciones de mundo específicos. Una manera de realizar estos ajustes consiste en, empleando y procurando información, orientar o pautar comportamientos y acciones humanas que se adecúan a un proyecto, designio o fin concebido. Martín Serrano distingue, entonces, entre información, organizaciones sociales y acciones sociales, y cree que lo que se ha acrecentado es la capacidad de algunos sectores para hacer que designios humanos específicos (los proyectos, las utopías, los propósitos, las concepciones de mundo) cuajen de manera efectiva, influyan y modulen las acciones sociales, las organizaciones y la información ${ }^{13}$. Serrano llama mediaciones a una enorme diversidad de instancias sociales y procedimientos (la familia, las terapias psicológicas, los medios de comunicación, la escuela, los partidos políticos), cuyos efectos pueden ser materiales, cognitivos o institucionales. 
Martín Serrano entiende que los medios de comunicación y, en particular, los medios informativos, atienden los cambios del entorno social, son sensibles a ello y, adicionalmente, son modificados institucionalmente por esos cambios (Martín Serrano, 1985/1997). "La tarea de los medios consiste en establecer (con acierto y error) los marcos de referencia adecuados para que los agentes sociales, incluidos ellos mismos, se sitúen en el cambio" (Martín Serrano, 1985/1997, pág. 139). Asimismo, identifica una doble dinámica de los medios de comunicación respecto al devenir social, los cambios y acontecimientos sociales: por un lado, deben hacer el trabajo de inscribir esos acontecimientos en relación con las disputas, tensiones y tipos de interpretaciones, normas, valoraciones que diversos grupos sociales le dan a esos acontecimientos; y por otro lado, deben encarar lo que llama la imprevisibilidad de los acontecimientos, procurando en la medida de lo posible anticiparlos o, al menos, ajustarlos a "la manera de comunicar del propio medio" (Martín Serrano, 1985/1997, pág. 140). El autor llama "mediación cognitiva” a los procesos de interpretación, valoración y ajuste de los acontecimientos a un conjunto de valores, normas y modos de ver el mundo, unos modos de ver siempre en disputa y tensión. Y llama "mediación estructural" a los procedimientos de ajuste del medio a sus modos de comunicar lo imprevisible, sus técnicas, modos de construcción de relatos, maneras de expresar los acontecimientos. Mientras la mediación cognitiva opera en términos de tensión y conflicto entre acontecer/creer, es decir, acontecimiento y hacer creer un acontecimiento, inscribirlo en un horizonte razonable de interpretaciones; la mediación estructural en cambio se inscribiría en la tensión entre acontecer/prever, esto es estructurar los procedimientos que permitan al medio anticiparse y narrar lo no previsto ${ }^{14}$.

Si un acontecimiento, según la terminología de Martín Serrano -o un evento, de acuerdo con la denominación que prefiero emplear en este artículo- constituye una entidad infinita, el evento mediatizado es, necesariamente, el resultado de poderosos procedimientos de reducción y esquematización derivados de mediaciones tanto estructurales como cognitivas. De esta manera, la protesta de las Madres Comunitarias (una compleja red infinita de eventos) termina convertida en una fotografía que privilegia su desnudez y una nota periodística que - sin examinar con cuidado las cifras- destaca la versión de la funcionaria del ICBF. Pero los procesos de comunicación social, de mediatización y viralización no cesan, y no podemos anticipar, de ninguna manera, qué transformaciones sociales podrán derivarse de este evento y de las diversas mediatizaciones que procurará; no podemos saber qué nuevas mediatizaciones emergerán con los días y de qué manera esas nuevas mediatizaciones alentarán en otros agentes sociales iniciativas similares; no podemos anticipar completamente si las burocracias a cargo podrán administrar, controlar y moldear el movimiento de protesta en curso asimilándolo a sus propios designios, pues -aunque hay desigual distribución de los recursos y condiciones para modular el devenir de las sociedades-, también los grupos sociales excluidos y objeto de control y sojuzgamiento han probado ayer y hoy una rica tradición de tácticas, estratagemas y procedimientos de modulación de la historia.

$\mathrm{Si}$ alguien tiene dudas sería bueno que se asomara a las secciones de comentarios de las publicaciones periodísticas on line: la algarabía procaz, burlona, insultante e insolente de los lectores, los usuarios, los comentaristas anónimos, nos recuerdan cómo un vigoroso cinturón de $e C s$ está remodulando, resistiendo y resemantizando sin más lo que quiere imponer y decir o se esfuerza en hacer creer el periódico o el medio de comunicación social apelando al lenguaje del decoro y la moderación. 


\section{Notas}

${ }^{1}$ Miembro del Grupo de Investigación en Periodismo e Información de la Universidad del Valle. Este artículo deriva de un proyecto de estudio en curso titulado Curadurías, en que estudiantes de la asignatura Debates Periodísticos y el profesor, han venido examinando desde agosto de 2013 algunas transformaciones fundamentales en periodismo, comunicación no mediática, comunicación pública mediática y comunicación en la web.

${ }^{2}$ La primera versión de este estudio fue publicada en 1981, en francés, bajo el título Construire l'evénement: les médias et l'accident de Three Mile Island, por Éditions du Minuit, Paris.

${ }^{3}$ Como se sabe, Dayan y Katz (1995) postulan la triple condición del “acontecimiento" extrapolando y haciendo converger tres categorías lingüísticas: "Una ceremonia interrumpe el flujo de la vida cotidiana (sintáctica) trata con reverencia un material sacro (semántica) e implica la respuesta (pragmática) de un público comprometido” (Dayan \& Katz, 1995, pág. 20). Diferencian tres tipos de acontecimientos mediáticos: Competición (vg. Final de Mundial de Fútbol), Conquista (vg., Alunizaje del Apolo XI el 16 de junio de 1969, y Coronación (vg., matrimonio real de Diana de Gales y Carlos de Inglaterra el 29 de julio 1981).

${ }^{4}$ La versión on line de la nota puede consultarse en el siguiente enlace: http:/ /www.eltiempo.com/vida-de-hoy/ARTICULOWEB-NEW_NOTA_INTERIOR-13114926.html

${ }^{5}$ Hace carrera, de un tiempo para acá, entre funcionarios públicos y empresarios, hablar de montos globales de dinero (inversiones, recursos, fondos) cuando se los conmina a explicar cómo se están resolviendo problemas específicos. Y es usual que los medios de comunicación y los periodistas asumamos esas cifras sin más. En este caso, González Maxcyclak indica que se aprobaron para el próximo año 130.000 millones $\left(130 \times 10^{9}\right)$ para el pago de 69000 madres comunitarias que cuidan a 1.077.000 menores de cinco años. La nota de prensa se limita a reproducir las tres cifras. Ya es problemático reproducirlas sin hacer una mínima labor de verificación. El periódico se contenta con atribuir a la fuente esta información, con lo cual se dispensa del resto. Pero lo más interesante es que, si las cifras son correctas, bastaría un simple ejercicio de división para ver lo escandaloso de la situación. Cada madre, en promedio, tiene a su cargo 15 niños menores de 5 años. Cualquiera que haya atendido a un niño sabe, como dice el viejo proverbio africano, que se requiere una tribu para cuidarlo. Basta imaginarse las dimensiones del trabajo de estas mujeres, acogiendo en sus casas, a 15 niños. La funcionaria del ICBF dice que requieren cualificación y formación, y deja entrever que su pago -bonificación equivalente a un salario mínimo- se ajusta a su nivel de formación (no son técnicas, tecnólogas ni profesionales universitarias). Conozco la labor de algunas madres comunitarias de Aguablanca y su trabajo es, de lejos, bastante digno y esforzado, tienen responsabilidades de nutrición, aprestamiento escolar, recreación, aseo y limpieza, control y regulación de conflictos, juego y entretenimiento, cuidados en salud. Trabajan todos los días hábiles, desde las 6 o 7 de la mañana y hasta después de almuerzo.

Pero lo más sorprendente es que si se divide el monto aprobado para el próximo año por el número de madres comunitarias, el pago sería de 157.000 pesos, una cuarta parte de un salario mínimo. Algo huele mal tras estas cifras, ¿cierto? Lo interesante es que con la nota todos quedan más o menos contentos: el periódico publicó el hecho, el periodista hizo su trabajo, la funcionaria pública defendió la labor del ICBF y dio la cara, y las Madres Comunitarias hicieron visible y pública su protesta.

${ }^{6}$ Efectos que dependen de la efectiva conexión entre sistemas. Vale la pena la mención para salir de la exagerada metáfora del aleteo de una mariposa en un salón de la Universidad del Valle que produce un huracán en China. Esta exageración ha sido ampliamente desmentida por Edward Lorenz, meteorólogo y uno de los autores que más contribuyó al desarrollo de las teorías del caos y de los sistemas dinámicos (Figura 1).

${ }^{7}$ Que, vale la pena insistir, son infinitos internamente, esto es están hechos de infinidad de eventos pasados, presentes y futuros.

${ }^{8}$ Designo con 'e' minúscula a 'E', cuando es mediatizado, indicando con ello que $e$ es una derivación menor, siempre parcial, siempre incompleta, producto de variados procedimientos de selección, parafraseo, reinvención, recreación, recomposición y-qué le vamos a hacer- mutilación y hasta falsificación de E.

${ }^{9}$ Para que pueda apreciarse la profundidad y eficacia de los eCs, piénsese por un momento en la manera como, en una ciudad, se corre la voz sobre un nuevo lugar de rumba o un restaurante o una hamburguesería de barrio. Sin mediatización alguna, estos lugares pueden hacerse notablemente populares. Igual pasa con marcas underground, lugares de distribución de drogas ilegales, ventas de mercancía robada, metederos extraños, etc. Las aglomeraciones de personas alrededor de las pirámides especulativas y estafas tipo Ponzi en 1996 (el juego del avión) y en 2008, ilustran y se fundan en redes sociales de comunicación no mediáticas catalizadas por eCs.

${ }^{10}$ Es probable que en algunos casos la mediatización favorezca la viralización, aunque - creo- lo normal es que la viralización de un evento web favorezca su mediatización, y esta mediatización - a la vez-empuje nuevas oleadas virales. 
${ }^{11}$ El director de cine Víctor Gaviria ha intentado llevar a la pantalla grande algunos aspectos de la vida de Sangre Negra. Esto es hay un EM en curso, que podría relanzar otro evento mediático previo (la biografía escrita por Pedro Claver Téllez) y los archivos de prensa y radio sobre Sangre Negra, Jacinto Cruz Osma (1932-1964). Pedro Claver Téllez (1987; 1993; 1995) ha escrito las biografías de varios bandoleros de la primera mitad del siglo XX: José William Aranguren o Desquite (1936-1964), Teófilo Rojas Varón o El Chispas (1930-1963), Efraín González o el Siete Colores (1933-1965). Nótese, además, cómo el mundo académico - tal como hace el cine o la televisión-puede contribuir a revitalizar eventos. Una tesis doctoral, por ejemplo, se ha ocupado de pensar y estudiar a los bandoleros de la primera mitad del siglo XX en Colombia desmarcándose del usual abordaje periodístico - que los ha tratado como delincuentes-y pensándolos como agentes de formas primitivas de insurrección (Steiner, 2006).

${ }^{12}$ Por supuesto, la relevancia histórica de la muerte de Gaitán no es, de ninguna manera, equivalente a la victoria de la selección colombiana de fútbol sobre la argentina. Sin embargo, interesa subrayar que ambos eventos - para conservar su centralidad e importancia en la actualidad, requieren de procesos vivos y continuos de mediatización, comunicación social no mediática y ciertos niveles de viralización web, esto es, sistemas escolares en que se habla y narra El Bogotazo, publicaciones periodísticas que hacen especiales destacando las efemérides de estos eventos, revisiones y foros académicos que examinan y estudian este evento histórico y se intenta recrear y repensar su papel capital en la historia contemporánea del país, conversaciones de adultos mayores recontando los años de la Violencia en la década del 1950, o discusiones triviales de jóvenes y adultos dirimiendo cuál fue más importante, el 5 a 0 o el 4 a 4 de Colombia contra la Unión Soviética el 3 de junio de 1962.

${ }^{13}$ La visión de Martín Serrano contrasta, de manera significativa, con algunos planteamientos de Norbert Elias (1998) para quien los niveles de control y dominio de los seres humanos sobre las relaciones sociales, sobre los aspectos humanos de la vida social, son mucho más precarios, frágiles e incipientes que el dominio humano sobre los aspectos no humanos (vida natural, ciencias naturales, tecnologías).

${ }^{14}$ Un ejemplo elocuente de los procedimientos de previsión de los medios, de anticipación, puede apreciarse al leer el precioso perfil que Gay Talese (2008, págs. 203-218) hace de Alden Whitman, Don Malas Noticias, un singular escritor de obituarios de The New York Times. En medio de este delicioso perfil, el lector se entera de la existencia, en la dama gris, de un lugar llamado la morgue, en donde reposan obituarios, perfiles, necrológicas y pequeñas biografías de hombres y mujeres públicos. Lo interesante es que estos perfiles se hacen de manera anticipada, antes de que las personas mueran. También la existencia de manuales, procedimientos estandarizados de escritura, tips, fórmulas, formatos y pautas de organización de información son algunos de los recursos de estas mediaciones estructurales, estos modos de hacer tratable lo no siempre previsible.

\section{Referencias}

Castoriadis, C. (1991). Reflexiones sobre el desarrollo y la racionalidad. En F. Viviescas, \& F. Giraldo (Edits.), Colombia: El despertar de la modernidad (págs. 90-111). Bogotá: Foro Nacional Por Colombia.

Dayan, D., \& Katz, E. (1995). La historia en directo. La retransmisión televisiva de los acontecimientos. (E. Olcina i Aya, Trad.) Barcelona: Editorial Gustavo Gili.

Elias, N. (1998). ¿Cómo pueden las utopías científicas y literarias influir sobre el futuro? En V. Weiler (Ed.), Figuraciones en proceso (págs. 15-44). Bogotá: Fundación Social, Universidad Nacional de Colombia \& Universidad Industrial de Santander.

Martín Serrano, M. (1985/1997). La mediación de los medios. En J. Martín Barbero, \& A. Silva (Edits.), Proyectar la comunicación (págs. 137-156). Bogotá: Tercer Mundo Editores.

Steiner, C. (Enero-Junio de 2006). Un bandolero para el recuerdo: Efraín González también conocido como “El siete colores”. Antípoda. Revista de Antropología y Arqueología, 229-252. Recuperado el 21 de Febrero de 2013, de http:/ /antipoda. uniandes.edu.co/view.php/27/view.php

Talese, G. (2008). Retratos y encuentros. (C. J. Restrepo, Trad.) Madrid: Editoriales Aguilar, Altea, Taurus y Alfaguara.

Téllez, P. C. (1987). Crónicas de la vida bandolera: historia de los bandidos colombianos más famosos del siglo XX. Bogotá: Editorial Planeta.

Téllez, P. C. (1993). Efraín González: la dramática vida de un asesino asesinado. Bogotá: Editorial Planeta.

Téllez, P. C. (1995). La hora de los traidores: la cacería de Sangrenegra. Bogotá: Panamericana Editorial.

Verón, E. (2002). Construir el acontecimiento: los medios de comunicación masiva y el accidente de la central nuclear de Three Mile Island. Barcelona: Gedisa. (B. Anastasi de Lonné, \& H. Verbitsky, Trads.) Barcelona: Gedisa. 